\title{
Experimental work on Plain Cement Concrete Partially Replaced with Tannery Sludge
}

\author{
S. Venkatraman, K. Sathish Kumar, C. Anish, A. Mani
}

\begin{abstract}
This paper presents the result of an experimental study performed to investigate the effects of partial replacement of cement with tannery sludge mixture. The experiment deals with the compressive strength of concrete using tannery sludge mixture at different proportions. The resulting strength is compared with the concrete made up of $100 \%$ OPC i.e. control cube. The results obtained from compression tests are analyzed to identify the optimum proportion of tannery sludge mixture that can be replaced with cement to achieve the determined strength of the concrete. Many trails have been carried out and we have seen that the strength of concrete has successfully proved to increase in proportion to the sludge added. The highest strength is seen for $25 \%$ of sludge replaced for cement. Hence, from this investigation the partial replacement of cement by tannery sludge can be confidently recommended for future study on tannery sludge as a proving partial replacement for cement for an economic material purchase as well as enhancement of conservation of resources.
\end{abstract}

Keywords-Cement concrete, Tannery sludge.

\section{INTRODUCTION}

\section{A. General}

Preservation Energy plays a crucial role in growth of developing countries like India. In the context of low availability of non-renewable energy resources coupled with importance of using industrial waste cannot be underestimated. Tanning is an ancient craft in India and has been practiced for many centuries as an industrial operation at the village level. With the progress of time, however, it has acquired the status of a mature industry playing an important role in the country's economy. The industry flourishes in supply of raw materials (hides and skins) amounting for $15 \%$ of cattle, $46 \%$ of buffalo, $17 \%$ of goat and $4 \%$ of sheep of the world. The total annual protection of leather industry is about Rs.50-60 millions. Although tanning industry has been in existence for a long time, the problems of environmental pollution receive serious consideration only in recent years. The pollutants from large number of tanneries in the country have caused considerable demand of water courses and irrigation. It is realized that the untreated tannery sludge when allowed to stagnate, gives rise to odor nuisance,

Revised Manuscript Received on December 11, 2019 Engineering,,Bharath Institution Of Higher Education And Research,TamilNadu, India .Email: mailmagik@yahoo.com

K. Sathish Kumar, Assistant Professor, Department Of Civil Engineering,,Bharath Institution of Higher Education And Research,TamilNadu, India Email sathish_4549@yahoo.co.in

C. Anish, Asistant Professor, Department Of Civil Engineering,,Bharath Institution of Higher Education And Research,TamilNadu, India Email anishdavidpaul@gmail.com

A. Mani Professor, Department Of Civil Engineering,,Bharath Institution of Higher Education And Research,TamilNadu, India Email maniathi57@yahoo.in
S. Venkatraman, Assistant Professor,,Department Of Civil

unsightly appearance, creating ground and surface water pollution. The article gives an overview of the ultimate utilization of tannery sludge waste inclusive of its waste characteristics, pollution impacts and various disposal techniques, which have been experimented in this project. India produces nearly $10 \%$ of the total global availability of hides and skins, basic raw materials for the leather industry. There are around 23million pieces of cattle hides, 82 million pieces of goat skins and 29million pieces of sheep skins generated in India in 2003. In India as per 2008 statistics around 2 billion sq. $\mathrm{ft}$ of finished leather per annum was produced and it has been facing serious disposal problems. Using the experimental data, pavement section is designed. The relative cost of the pavement section with OPC as well as various proportions of tannery sludge is estimated and compared. It is observed that leather industry tan waste.[1]-[6]

\begin{tabular}{|c|c|c|c|c|}
\hline S.NO & PARTICULARS & TRIAL 1 & TRIAL 2 & TRIAL 3 \\
\hline 1 & $\begin{array}{l}\text { Temperature } \\
\text { during test }\left({ }^{\circ} \mathrm{c}\right)\end{array}$ & 25 & 25 & 25 \\
\hline 2 & $\begin{array}{l}\text { Empty weight } \\
\text { of bottle, } w_{1}(g)\end{array}$ & 41.49 & 41.49 & 41.49 \\
\hline 3 & $\begin{array}{c}\text { Weight of } \\
\text { bottle }+ \\
\text { cementitious } \\
\text { material (g) }\end{array}$ & 56.80 & 57.12 & 56.56 \\
\hline 4 & $\begin{array}{c}\text { Weight of } \\
\text { bottle }+ \\
\text { cementitious } \\
\text { material } \\
\text { + kerosene (g) }\end{array}$ & 89.85 & 89.13 & 88.90 \\
\hline 5 & $\begin{array}{c}\text { Weight of } \\
\text { bottle }+ \\
\text { kerosene }(g)\end{array}$ & 80.20 & 79.81 & 81.03 \\
\hline 6 & $\begin{array}{c}\text { Specific gravity } \\
\left(\mathrm{G}_{\mathrm{s}}\right)\end{array}$ & 2.643 & 2.581 & 2.70 \\
\hline 7 & $\begin{array}{c}\text { Average } \\
\text { specific gravity }\end{array}$ & 2.64 & 2.64 & 2.64 \\
\hline
\end{tabular}

Table 1:Specific Gravity Test for Cement

\begin{tabular}{|c|c|c|c|c|}
\hline $\begin{array}{c}\text { IS } \\
\text { sieve }\end{array}$ & $\begin{array}{c}\text { Wt.of soil } \\
\text { retained }\end{array}$ & $\begin{array}{c}\text { Cumulative } \\
\text { soil retained, } \\
\text { W }_{\text {d }}\end{array}$ & $\begin{array}{c}\text { Soil } \\
\text { retained } \\
\% \text { of } \\
\text { partial } \\
\text { sample }\end{array}$ & $\begin{array}{c}\text { Soil } \\
\text { passing } \\
\text { as \% of } \\
\text { partial } \\
\text { sample }\end{array}$ \\
\hline 4.75 & 0.23 & 0.23 & 0.046 & 99.024 \\
\hline 2.36 & 0.8 & 5.55 & 1.11 & 98.89 \\
\hline 1.18 & 81.59 & 82.62 & 16.524 & 83.476 \\
\hline 0.71 & 92.82 & 175.44 & 35.688 & 64.012 \\
\hline 0.6 & 135.88 & 311.09 & 62.218 & 37.782 \\
\hline 0.425 & 61.76 & 373.08 & 74.616 & 25.384 \\
\hline 0.3 & 23 & 396.08 & 79.216 & 20.784 \\
\hline 0.15 & 92.82 & 488.67 & 97.734 & 2.266 \\
\hline 0.075 & 5.5 & 494.4 & 98.83 & 1.12 \\
\hline
\end{tabular}


Sieve Analysis Test

\section{CASTING AND TESTING OF SPECIMEN}

\section{A. Trial Specimens:}

Since the tannery sludge has a non-uniform grain size, and also sine, we have found it as a replacement for cement, the sludge is sieved using 0.75 micron sieve and brought equal to the fineness of cement. Concrete cubes are casted with the mix design of M20 grade. Classifying into trials, the tannery sludge is added in increasing proportions as a replacement for cement. The compressive strength of the concrete cubes partially replaced with the tannery sludge is calculated for each trial.

TRIAL 1:

$5 \%$ tannery sludge is used as replacement for cement. In this trial, $5 \%$ of sludge is replaced for cement, 9 cubes in total are casted, for 7 days, 14 days and 28 days curing, allotting 3 cubes each. Curing was done, and the compressive strength for 7 days was obtained as 9.62 $\mathrm{N} / \mathrm{mm}^{2}$.

TRIAL 2:

$10 \%$ tannery sludge is used as a replacement for cement. In this trial, $10 \%$ of sludge is replaced for cement for cement. 9 cubes in total are casted, for 7 days, 14 days and 28 days curing, allotting 3 cubes each. Curing was done, and the compressive strength for 7 days was obtained as $9.78 \mathrm{~N} / \mathrm{mm}^{2}$. TRIAL 3:

$15 \%$ tannery sludge is used as a replacement for cement. In this trial, $15 \%$ of sludge is replaced for cement. 9 cubes in total are casted, for 7 days, 14 days and 28 days curing, allotting 3 cubes each. Curing was done, and the compressive strength for 7 days was obtained as $10.29 \mathrm{~N} / \mathrm{mm}^{2}$.

TRIAL 4:

$20 \%$ tannery sludge is used as a replacement for cement. In this trial, $20 \%$ of sludge is replaced for cement. 9 cubes in total are casted, for 7 days, 14 days and 28 days curing, allotting 3 cubes each. Curing was done, and the compressive strength for 7 days was obtained as $15.32 \mathrm{~N} / \mathrm{mm}^{2}$.

TRIAL 5:

$25 \%$ tannery sludge is used as a replacement for cement. In this trial, $25 \%$ of sludge is replaced for cement. 9 cubes in total are casted, for 7 days, 14 days and 28 days curing, allotting 3 cubes each. Curing was done, and the compressive strength for 7 days was obtained as $19.25 \mathrm{~N} / \mathrm{mm}^{2}$.[6]-[12]

\section{MATERIALS \& METHODS}

\section{A. Test On Hardened Concrete}

\section{Compressive Test Results}

The compressive strength of concrete was found out by placing the concrete cube of size $150 \mathrm{~mm} \times 150 \mathrm{~mm}$ in the compressive testing machine. The compressive test was carried out for 7 days, 14 days and 28 days for the different percentage replacement of tannery sludge with cement as stated above. The values were read from the dial of the compressive testing machine in terms of load applied MPa. Then the load was divided by area of the cube to find out the strength of the concrete cube. The test results of the compression test are tabulated.

\section{RESULTS}

Compressive strength of Trial 1 ( $5 \%$ of tannery sludge):

\begin{tabular}{|c|c|l|l|l|l|}
\hline Trial & Days & \multicolumn{2}{|l|}{$\begin{array}{l}\text { Compressive } \\
\left({\left.\mathrm{N} / \mathrm{mm}^{2}\right)}^{2}\right.\end{array}$} & strength & $\begin{array}{l}\text { Average } \\
\text { Cpmpressive } \\
\text { Strength } \\
\left(\mathrm{N} / \mathrm{mm}^{2}\right)\end{array}$ \\
\cline { 2 - 6 } & & $\mathrm{A}$ & $\mathrm{B}$ & $\mathrm{C}$ & \\
\hline \multirow{3}{*}{ Trial $1(5 \%)$} & 7 & 8.88 & 9.77 & 10.22 & 9.42 \\
\cline { 2 - 6 } & 14 & 16.85 & 17.40 & 14.22 & 14.21 \\
\cline { 2 - 5 } & 28 & 27.80 & 28.16 & 28.56 & 28.36 \\
\hline
\end{tabular}

Compressive strength of Trial $2(10 \%$ of tannery sludge)

\begin{tabular}{|c|c|c|c|c|c|}
\hline \multirow[t]{2}{*}{ Trial } & \multirow[t]{2}{*}{ Days } & \multicolumn{3}{|c|}{$\begin{array}{l}\text { Compressive strength } \\
\left(\mathrm{N} / \mathrm{mm}^{2}\right)\end{array}$} & \multirow{2}{*}{$\begin{array}{l}\text { Average } \\
\text { Compressive } \\
\text { Strength } \\
\left(\mathrm{N} / \mathrm{mm}^{2}\right)\end{array}$} \\
\hline & & $\mathrm{A}$ & B & $\mathrm{C}$ & \\
\hline \multirow{3}{*}{ Trial $2(10 \%)$} & 7 & 9.33 & 9.77 & 1022 & 9.78 \\
\hline & 14 & 14.60 & 14.80 & 15.50 & 14.97 \\
\hline & 28 & 28.50 & 29.14 & 29.64 & 29.34 \\
\hline
\end{tabular}

Compressive strength of Trial 1 (5\% of tannery sludge):

Compressive strength of Trial $1(25 \%$ of tannery sludge):

\begin{tabular}{|c|c|c|c|c|c|}
\hline \multirow[t]{2}{*}{ Trial } & \multirow[t]{2}{*}{ Days } & \multicolumn{3}{|c|}{$\begin{array}{l}\text { Compressive strength } \\
\left(\mathrm{N} / \mathrm{mm}^{2}\right)\end{array}$} & \multirow{2}{*}{$\begin{array}{l}\text { Average } \\
\text { Compressive } \\
\text { Strength } \\
\left(\mathrm{N} / \mathrm{mm}^{2}\right)\end{array}$} \\
\hline & & $\mathrm{A}$ & B & $\mathrm{C}$ & \\
\hline \multirow{3}{*}{ Trial $5(25 \%)$} & 7 & 18.66 & 19.10 & 20 & 19.25 \\
\hline & 14 & 21.33 & 22.22 & 22.36 & 22.07 \\
\hline & 28 & 35.84 & 36.45 & 36.74 & 36.81 \\
\hline
\end{tabular}

Compressive strength of Trial $1(15 \%$ of tannery sludge):

\begin{tabular}{|c|c|c|c|c|c|}
\hline \multirow[t]{2}{*}{ Trial } & \multirow[t]{2}{*}{ Days } & \multicolumn{3}{|c|}{$\begin{array}{l}\text { Compressive strength } \\
\left(\mathrm{N} / \mathrm{mm}^{2}\right)\end{array}$} & \multirow{2}{*}{$\begin{array}{l}\text { Average } \\
\text { Compressive } \\
\text { Strength } \\
\left(\mathrm{N} / \mathrm{mm}^{2}\right)\end{array}$} \\
\hline & & A & B & $\mathrm{C}$ & \\
\hline \multirow{3}{*}{ Trial $3(15 \%)$} & 7 & 10 & 10.20 & 10.66 & 10.29 \\
\hline & 14 & 14.66 & 15.10 & 16.80 & 15.50 \\
\hline & 28 & 30.56 & 31.10 & 30.94 & 31 \\
\hline
\end{tabular}

Compressive strength of Trial $1(20 \%$ of tannery sludge $)$ :

\begin{tabular}{|c|c|c|l|l|l|}
\hline Trial & Days & \multicolumn{2}{|l|}{$\begin{array}{l}\text { Compressive strength } \\
\left({\mathrm{N} / m^{2}}^{2}\right)\end{array}$} & $\begin{array}{l}\text { Average } \\
\text { Compressive } \\
\text { Strength } \\
\left(\mathrm{N} / \mathrm{mm}^{2}\right)\end{array}$ \\
\cline { 3 - 6 } & & $\mathrm{A}$ & $\mathrm{B}$ & $\mathrm{C}$ & 15.32 \\
\hline \multirow{3}{*}{ Trial 4(20\%) } & 7 & 14.66 & 15.33 & 16 & 15 \\
\cline { 2 - 6 } & 14 & 20.44 & 20.80 & 22.22 & 21.15 \\
\cline { 2 - 6 } & 28 & 33.90 & 34.96 & 34.74 & 34.44 \\
\hline
\end{tabular}

\section{CONCLUSION}

Conclusion Based On Test Performed:

Replacement of cement by tannery sludge has seenthe following conclusion.

1. Usage of tannery sludge as a replacement has given a comparatively high compressive strength.

2. Addition of the sludge proportional to the cement in increasing percentage has resulted in proportionately increasing compressive strength

3 . The highest compressive strength obtained from the trials is $25 \%$ of sludge for replacement of the cement.

4. As clearly understood, the cement can be partially replaced by further increasing percentage of the sludge to gain further high compressive strength of the concrete.

5. The objective of bringing a conservative method of construction and having an economic use of materials is also 
ultimately achieved in this experimental investigation.

\section{REFERENCES}

1. Iyappan L., Dayakar P., Identification of landslide prone zone for coonoortalukusing spatial technology, International Journal of Applied Engineering Research,V-9,I-22,PP-5724-5732,Y-2014.

2. Kumar J., Sathish Kumar K., Dayakar P.,Effect of microsilica on high strength concrete, International Journal of Applied Engineering Research,V-9,I-22,PP-5427-5432,Y-2014.

3. Dayakar P., Vijay Ruthrapathi G., Prakesh J., Management of bio-medical waste, International Journal of Applied Engineering Research,V-9,I-22,PP-5518-5526,Y-2014.

4. Swaminathan N., Dayakar P., Resource optimization in construction project, International Journal of Applied Engineering Research,V-9,I-22,PP-5546-5551,Y-2014

5. Venkat Raman K., Dayakar P., Raju K.V.B.,An experimental study on effect of cone diameters in penetration test on sandy soil, International Journal of Civil Engineering and Technology,V-8,I-8,PP-1581-1588,Y-2017.

6. Meikandaan T.P., Ramachandra Murthy A.,Retrofittng of reinforced concrete beams using GFRP overlays,International Journal of Civil Engineering and Technology,V-8,I-2,PP-423-439,Y-2017

7. Ilayaraja K., Krishnamurthy R.R., Jayaprakash M., Velmurugan P.M., Muthuraj S.,Characterization of the 26 December 2004 tsunami deposits in Andaman Islands (Bay of Bengal, India),Environmental Earth Sciences,V-66,I-8,PP-2459-2476,Y-2012

8. Ilayaraja K.,Morphometric parameters of micro watershed in Paravanar sub-basin, Cuddalore District,International Journal of Civil Engineering and Technology,V-8,I-8,PP-1444-1449,Y-2017

9. Ilayaraja K., Singh R.K., Rana N., Chauhan R., Sutradhar N.,Site suitability assessment for residential areas in south Chennai region using remote sensing and GIS techniques,International Journal of Civil Engineering and Technology,V-8,I-8,PP-1468-1475,Y-2017

10. Ilayaraja K., Reza W., Kumar V., Paul S., Chowdhary R.,Estimation of land surface temperature of Chennai metropolitan area using Landsat images,International Journal of Civil Engineering and Technology,V-8,I-8,PP-1450-1456,Y-2017

11. Chitra R.,Experimental study on beam using steel fiber and latex,International Journal of Civil Engineering and Technology,V-8,I-8,PP-1395-1403,Y-2017

12. Chitra R.,Analysis of traffic and management at Kovilambakkam intersection,International Journal of Civil Engineering and Technology,V-8,I-8,PP-1433-1443,Y-2017

13. Aswathy M.,Experimental study on light weight foamed concrete,International Journal of Civil Engineering and Technology,V-8,I-8,PP-1404-1412,Y-2017

14. Aswathy M.,Wastewater treatment using constructed wetland with water lettuce (Eichornia Crasipies),International Journal of Civil Engineering and Technology,V-8,I-8,PP-1413-1421,Y-2017

15. Kiruthiga K., Anandh K.S., Gunasekaran K, Assessment of influencing factors on improving effectiveness and productivity of construction engineers, 2015, International Journal of Applied Engineering Research, V - 10,I -17,p -13849-13854.

\section{AUTHORS PROFILE}



S. Venkatraman, Assistant Professor,,Department Of Civil Engineering,,Bharath Institution Of Higher Education And Research,TamilNadu, India

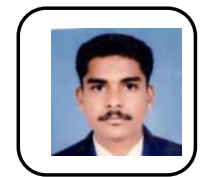

K.Sathish Kumar Assistant Professor,„Department O Civil Engineering,,Bharath Institution Of Higher Education And Research,TamilNadu, India .

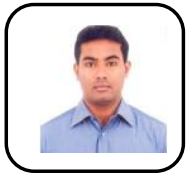

C. Anish, Asistant Professor, Department Of Civil Engineering,,Bharath Institution of Higher Education And Research,TamilNadu, India



A.Mani Professor, Department Of Civil Engineering,,Bharath Institution Of Higher Education And Research,TamilNadu, India 